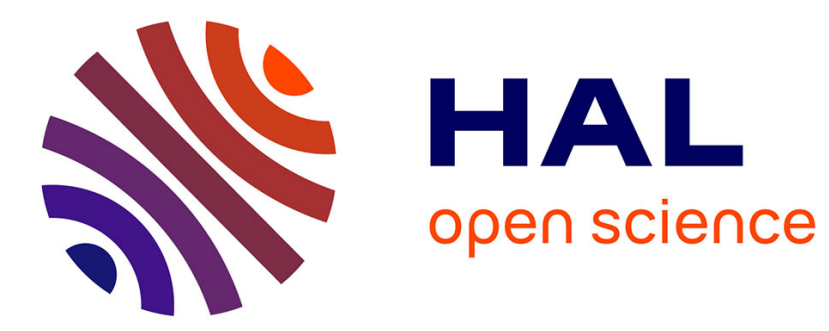

\title{
Assessment of a global climatology of oceanic dimethylsulfide (DMS) concentrations based on SeaWiFS imagery (1998-2001)
}

Sauveur Belviso, Cyril Moulin

\section{> To cite this version:}

Sauveur Belviso, Cyril Moulin. Assessment of a global climatology of oceanic dimethylsulfide (DMS) concentrations based on SeaWiFS imagery (1998-2001). [0] Notes des Activités Instrumentales de l'IPSL. 21, IPSL. 2002. hal-03319400

\author{
HAL Id: hal-03319400 \\ https://hal.science/hal-03319400
}

Submitted on 12 Aug 2021

HAL is a multi-disciplinary open access archive for the deposit and dissemination of scientific research documents, whether they are published or not. The documents may come from teaching and research institutions in France or abroad, or from public or private research centers.
L'archive ouverte pluridisciplinaire HAL, est destinée au dépôt et à la diffusion de documents scientifiques de niveau recherche, publiés ou non, émanant des établissements d'enseignement et de recherche français ou étrangers, des laboratoires publics ou privés. 
CNRS - Université Pierre et Marie Curie - Université Versailles-Saint-Quentin CEA - IRD - Ecole Normale Supérieure - Ecole Polytechnique

\section{Institut Pierre Simon Laplace des Sciences de l'Environnement Global}

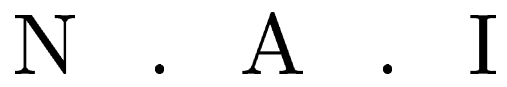

Notes des Activités Instrumentales INSTRUMENTS - EXPÉRIENCES - OBSERVATIONS

AsSESSMENT OF A GLOBAL CLIMATOLOGY OF OCEANIC DIMETHYLSULFIDE (DMS) CONCENTRATIONS BASED ON SEAWIFS IMAGERY (1998-2001)

Belviso S. ${ }^{1}$ and C. Moulin ${ }^{1}$

1 Institut Pierre Simon Laplace / Laboratoire des Sciences du Climat et de l'Environnement CEN/Saclay, Bat 709, L'Orme des Merisiers, 91191 Gif-surYvette, France
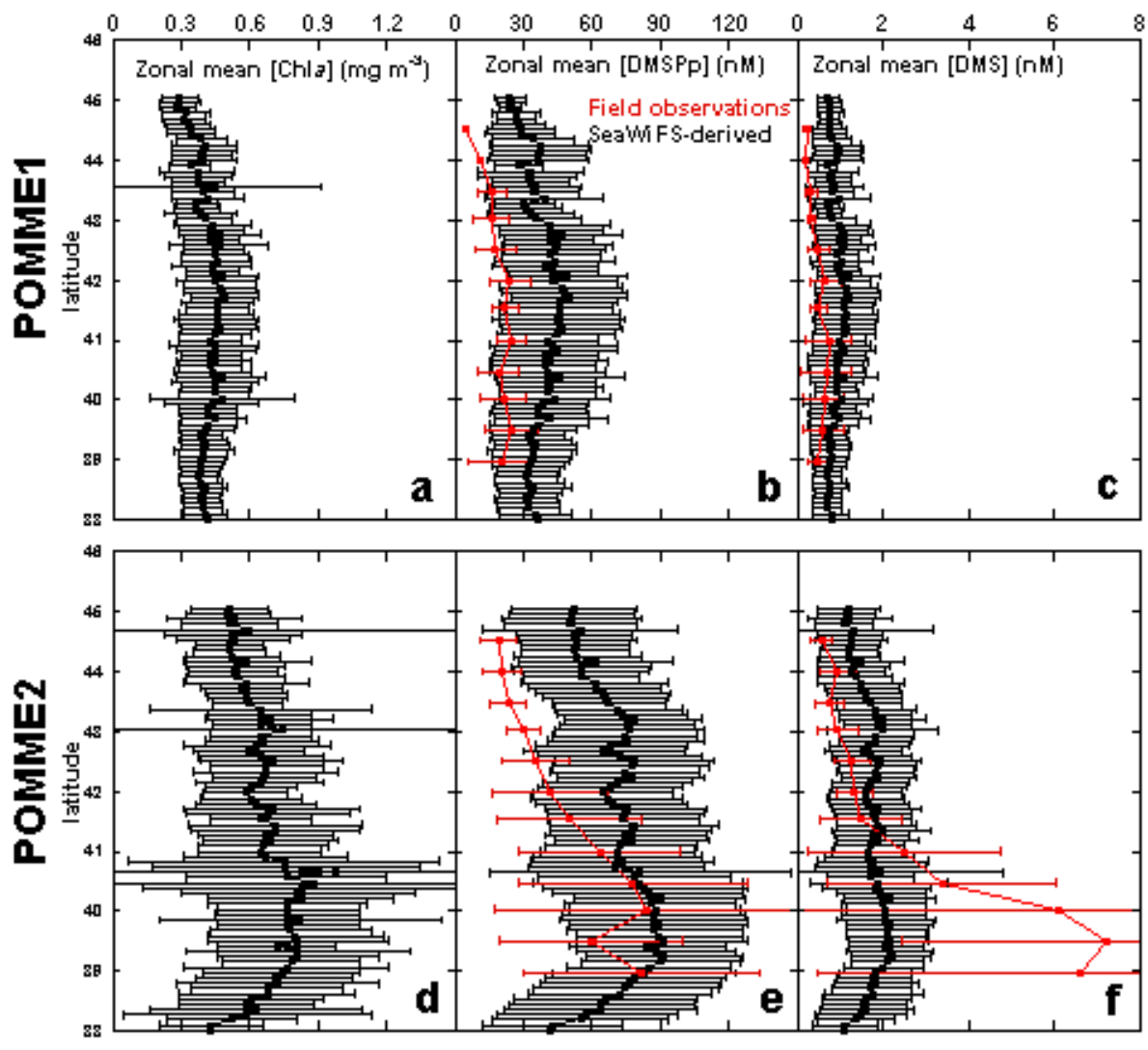

Mai 2002 / May 2002 - Note $\mathbf{n}^{\circ} 21$ 
Notes Des ACtivités Instrumentales De L'IPSL

\section{http://www.ipsl.jussieu.fr/documentation/NAI/index.htm}

- Directeur de la publication: Jean JOUZEL

- Responsable éditorial: $\quad$ Laurent MENUT [menut@lisa.univ-paris12.fr]

- Comité d'édition: Hélène CHEPFER (LMD)

Yves DANDONNEAU (LODyC)

Cyrille FLAMANT (SA)

Cyril MOULIN (LSCE)

Alain PROTAT (CETP)

Rémi ROCA (LMD)

Institut PierRe-Simon LAPLACE - http://www.ipsl.jussieu.fr

\begin{tabular}{ll}
\hline Université Pierre et Marie Curie & Université Versailles Saint Quentin \\
B 102 - T15 - E5 & Collège Vauban \\
4, place Jussieu & 47, boulevard Vauban \\
75252 Paris Cedex 05 & 78047 Guyancourt Cedex \\
\hline
\end{tabular}




\title{
Assessment of a global climatology of oceanic dimethylsulfide (DMS) concentrations based on SeaWiFS imagery (1998-2001)
}

\author{
S. Belviso and C. Moulin \\ Laboratoire des Sciences du Climat et de l'Environnement \\ CEN/Saclay, B t 709, L’Orme des Merisiers, 91191 Gif-sur-Yvette, France
}

\begin{abstract}
The flux of dimethylsulfide (DMS) from the world's oceans is the largest known source of biogenically-derived reduced sulfur compounds to the atmosphere. Its impact on atmospheric chemistry and radiative transfer is an active area of scientific research, and DMS is routinely included in three-dimensional global climate change and chemical transport models. In such models, DMS fluxes typically are based on global sea surface DMS concentrations and wind-speed-dependent parameterizations of the mass transfer coefficient. A method is developed to estimate sea surface particulate dimethylsulfoniopropionate (DMSPp) and DMS concentrations from sea surface concentrations of chlorophyll $a\left(\mathrm{Chl}^{\circ} a\right)$. When compared with Kettle and Andreae (2000), the $1 ; x 1 ;$ global climatology of oceanic DMS concentrations computed from four years (1998-2001) of SeaWiFS Chl ${ }^{\circ} a$ exhibits lower seasonal variability in the southern than in the northern hemisphere. A first evaluation of the method shows that it reasonably well represents DMSPp and DMS in the North Atlantic subtropical gyre, in large blooms of mixed populations of diatoms and Phaeocystis sp., in massive blooms of Phaeocystis sp. but fails for large almost pure blooms of diatoms. SeaWiFS-derived DMSPp and DMS concentrations were also compared with spatially and temporally coincident in-situ measurements acquired independently in the Atlantic between $39{ }_{i} \mathrm{~N}$ and $45 i \mathrm{~N}$ and in subtropical and subantarctic Indian Ocean surface waters. Moderate spring and summer phytoplankton blooms there exhibited similar trends in DMSPp and DMS levels than in moderate blooms of mixed populations of prymnesiophytes and dinoflagellates investigated by others. Measured DMS largely exceeded simulated DMS concentrations whereas measured and simulated DMSPp levels were in close agreement. DMS accumulation is tentatively attributed to dinoflagellates DMSP lyase activity. Beyond these agreements and discrepancies, the results show that, contrary to the Kettle and Andreae (2000) climatology, the use of SeaWiFS $\mathrm{Chl}^{\circ} a$ maps enables to observe the meso-scale variability of DMS concentrations on a weekly basis.
\end{abstract}

Manuscript submitted to the SeaWiFS Special Issue of Deep Sea Res. (part II) 


\section{Introduction}

In order to assess the climate effects of anthropogenic sulfate aerosols in three-dimensional atmospheric models, it is also necessary to simulate spatial and temporal distributions of natural sulfur gases and aerosols emitted at the Earth's surface. Dimethylsulfide (DMS) is an important sulfur-compound produced naturally in the sea by the phytoplankton from its precursor dimethylsulfoniopropionate (DMSPp). DMS is present in the seawater at sufficient concentrations to sustain a large flux to the atmosphere, where it is photooxydized to form hygroscopic sulfur aerosols. Jones et al. (2001) recently obtained a value of $-1.9 \mathrm{~W} \mathrm{~m}^{-2}$ for the effects of anthropogenic sulfate aerosol on cloud albedo and on precipitation efficiency (the indirect sulfate aerosol forcing effects), and demonstrated in a sensitivity test that a doubling of oceanic DMS emissions would reduce the indirect effect by over $25 \%$. Thus, changes in natural DMS emissions appear to significantly affect estimates of the magnitude of anthropogenic sulfate forcing.

Many current atmospheric sulfur models rely on the global database of sea surface DMS concentration measurements assembled by Kettle et al. (1999) to compute the atmospheric fluxes of DMS. This database, initially derived from 15,617 measurements, was processed to create a monthly climatology on a $1 ;$ latitude $x 1_{i}$ longitude grid. Because this data set does not provide a complete coverage of the oceans, Kettle et al., following Longhurst et al. (1995), divided the Earth s oceans into a series of 57 biogeochemical provinces and calculated the average DMS concentration in each province. Several oceanic provinces are satisfactorily sampled (North Atlantic, Equatorial Pacific,...), but some others, mostly in the southern hemisphere, have so few data available that the average DMS concentration from an adjacent province was used to fill the gap. This global database of sea surface DMS concentrations was recently updated (Kettle and Andreae 2000; hereinafter referred K\&A2000), using observations collected in the South Subtropical Convergence, Subantarctic and North Atlantic Drift provinces by Sciare et al. (1999) and Belviso et al. (2000). The major drawback of this unique database is that the sea surface DMS concentrations in the poorly sampled oceanic provinces are subject to strong changes when new data are added to the data base.

Attempts to correlate DMS with variables that can be mapped globally have been carried out (Kettle et al., 1999). With respect to DMS concentration, the highest linear correlation was found with DMSPp concentration, but the coefficient of correlation $\left(\mathrm{r}^{2}\right)$ was only 0.24 . With respect to DMSPp, the highest correlation was found with chlorophyll a concentration 
$\left(\mathrm{Chl}^{\circ} a\right)$, but $\mathrm{r}^{2}$ was only 0.14 . These two relationships are thus not accurate enough to estimate the sea surface distribution of DMS from the global distribution of $\mathrm{Chl}^{\circ} a$ measured from space by ocean color sensors.

In a recent study by Anderson et al. (2001), the $\mathrm{Chl}^{\circ} a$ concentration of the K\&A2000 database, when available, was merged with global fields of nutrients and light to generate a CJQ index, where $\mathrm{C}$ is the chlorophyll concentration, $\mathrm{J}$ is the irradiance and $\mathrm{Q}$ is a nutrient term. This index is a proxy of the algal growth rate and is shown to be significantly correlated to sea surface DMS concentration in the range 2.3-22 nM. However, DMS variability in lowconcentration areas $(<2.3 \mathrm{nM})$ is not resolved by this relationship. This is certainly the major weakness of this method since low DMS levels account for about half of the DMS measurements of the K\&A2000 database and concern wide areas of the open ocean (high and mid latitudes in the winter hemisphere, subtropical gyres).

An alternative method is proposed in the modeling study of Aumont et al. (2002) which makes use of non-linear parameterizations to relate DMS concentration to $\mathrm{Chl}^{\circ} a$ and to a community structure index (Fp-ratio), both parameters being calculated independently within the global 3-D ocean carbon cycle model. Their results show that the use of the Fp-ratio in addition to $\mathrm{Chl}^{\circ} a$ leads to much realistic estimates of the sea surface DMS concentration. The major difficulty in using this method is that, contrary to $\mathrm{Chl}^{\circ} a$, the Fp-ratio is not routinely measured at the global scale.

In this study, we modified the method of Aumont et al. (2002) by estimating the Fp-ratio directly from $\mathrm{Chl}^{\circ} a$, so that sea surface DMS concentration can be computed solely from SeaWiFS ocean color measurements. We also slightly revised diagnostic relationships used by Aumont et al. (2002) to relate DMSPp and DMS concentrations to $\mathrm{Chl}^{\circ} a$ and Fp-ratio. The relevance of these relationships to predict DMSPp and DMS concentrations is assessed in different areas of the North Atlantic and Indian Oceans and a global monthly climatology of sea-surface DMS concentration based on four years (1998-2001) of SeaWiFS data is presented. The relevance of this climatology is assessed by comparison with K\&A2000 datasets and differences in term of global DMS distribution are discussed. 


\section{Description of the method}

The principle of our method is similar to that developed by Aumont et al. (2002). It relies basically on two relationships ${ }^{\circ}$ :

$$
\begin{aligned}
& \text { DMSPp } \left.\left.=\text { Micro-DMSPp f(Fp-ratio, } \mathrm{Ch}^{\circ} a\right)+ \text { Nano-DMSPp f(Fp-ratio, } \mathrm{Chl}^{\circ} a\right) \\
& \text { DMS }=\mathrm{f}(\text { DMSPp, Fp-ratio })
\end{aligned}
$$

where $\mathrm{Chl}^{\circ} \mathrm{a}$ is the sea-surface chlorophyll concentration and Fp-ratio is the community structure index. This index represents the proportion of micro-phytoplankton within the whole phytoplankton community and is defined as the ratio of the integrated concentrations of fucoxanthin and peridinin to the sum of the integrated concentrations of diagnostic pigments of all taxa in the phytoplanktonic community (Claustre et al., 1994). Contrary to the approach of Aumont et al. (2002), the Fp-ratio is diagnosed directly from $\mathrm{Chl}^{\circ} a$ in this study.

The three relationships used in Equations 1a and $1 \mathrm{~b}$ are obtained statistically using the scarce sets of coincident measurements of the required parameters. The amount of available data is thus crucial in this approach to ensure the validity of the relationships at the global scale. We used pigment measurements performed during five cruises carried out in the Atlantic Ocean, the Mediterranean Sea and the Indian Sector of the Southern Ocean (Belviso et al., 2001) to relate the Fp-ratio to the chlorophyll a concentration. Figure 1a shows that the proportion of microphytoplankton within the whole phytoplankton community increases non-linearly with $\mathrm{Chl}^{\circ} a$, the best fit relationship $\left(\mathrm{r}^{2}=0.89, \mathrm{n}=195\right)$ in the range $0-3.5 \mathrm{mg} \mathrm{m}^{-3}$ being $^{\circ}$ :

$$
\mathrm{Fp}=0.01682+\left(0.48047 \times \mathrm{Chl}^{\circ} a\right)-\left(0.062878 \times \mathrm{Chl}^{2}\right), \text { for } \mathrm{Chl}^{\circ} a+3.5 \mathrm{mg} \mathrm{m}^{-3}
$$

Despite the good correlation coefficient, the high dispersion of Fp-ratio data for $\mathrm{Chl}^{\circ} a$ lower than $0.5 \mathrm{mg}^{\circ} \mathrm{m}^{-3}$ in Figure 1a shows the limitation of this $\mathrm{Chl}^{\circ} a$-based approach to represent the complexity of phytoplankton communities in the open ocean. Due to the lack of high $\mathrm{Chl}^{\circ} a$ data, we used a conservative relationship to compute the Fp-ratio ${ }^{\circ}$

$$
\mathrm{Fp}=0.92, \text { for } \mathrm{Chl}^{\circ} a>3.5 \mathrm{mg} \mathrm{m}^{-3}
$$

The contribution of microphytoplankton (diatoms plus dinoflagellates) to the total concentration of $\mathrm{Chl}^{\circ} a$ is assumed to be $\mathrm{Fp} \times \mathrm{Chl}^{\circ} a$ (Vidussi et al., 2001). A ratio of 20 
$\mathrm{mmol}{ }^{\circ} \mathrm{g}^{-1}$ is taken to be typical of phytoplankton communities dominated by microphytoplankton, i.e. diatoms, and, to a lesser extent, dinoflagellates (Aumont et al., 2002). Micro-DMSPp in Equation 1a was thus parameterized as follows (see also Figure 1b) ${ }^{\circ}$ :

$$
\text { Micro-DMSPp }=20 \times \mathrm{Chl}^{\circ} a \times \mathrm{Fp}
$$

The diagnostic relationship of nano-DMSPp in Equation 1a used by Aumont et al. (2002) has been revised in an empirical way to improve the quality of the fit. A scatter plot of the contribution of the remaining phytoplankton community to $\mathrm{Chl}^{\circ} a$ and DMSPp (nano-Chl ${ }^{\circ} a$ and nano-DMSPp) is shown in Figure 1c. A new equation was developed whereby nanoDMSPp is invariant with $\mathrm{Chl}^{\circ} a$ in the range $0-0.3 \mathrm{mg} \mathrm{m}^{-3}$ and is a linear function of $\mathrm{Chl}^{\circ} a$ above $0.3 \mathrm{mg} \mathrm{m}^{-30}$ :

$$
\begin{aligned}
& \text { Nano-DMSPp }=21 \mathrm{nM}, \text { for nano-Chl }{ }^{\circ} a \dagger 0.3 \mathrm{mg} \mathrm{m}^{-3} \\
& \text { Nano-DMSPp }=356.4 \times \text { nano-Chl }^{\circ} a-85.5, \text { for nano-Chl } a>0.3 \mathrm{mg} \mathrm{m}^{-3}
\end{aligned}
$$

The diagnostic relationship of DMS used by Aumont et al. (2002) has also been revised by removing data from the Norwegian fjords because they are believed to not be relevant for global scale studies. These data will however be used in the following to independently evaluate the relevance of the diagnostics of DMSPp and DMS concentrations for coastal waters . The revised DMS-to-DMSPp ratios from the different cruises are plotted against Fpratios (in the range 0-0.92) in Figure 1d. These ratios are significantly correlated $\left(r^{2}=0.46\right.$, $\mathrm{n}=120$ ), the best fit being obtained with a fifth-order polynome ${ }^{\circ}$ :

$$
\mathrm{DMS} / \mathrm{DMSPp}=0.231-3.038 \times \mathrm{Fp}+16.0 \times \mathrm{Fp}^{2}-38.05 \times \mathrm{Fp}^{3}+41.12 \times \mathrm{Fp}^{4}-16.32 \times \mathrm{Fp}^{5}
$$

The sea surface DMS concentration can thus be deduced directly from the surface chlorophyll concentration measured at sea or from space by using Equations 1a, 2, 3, 4 and 5. 

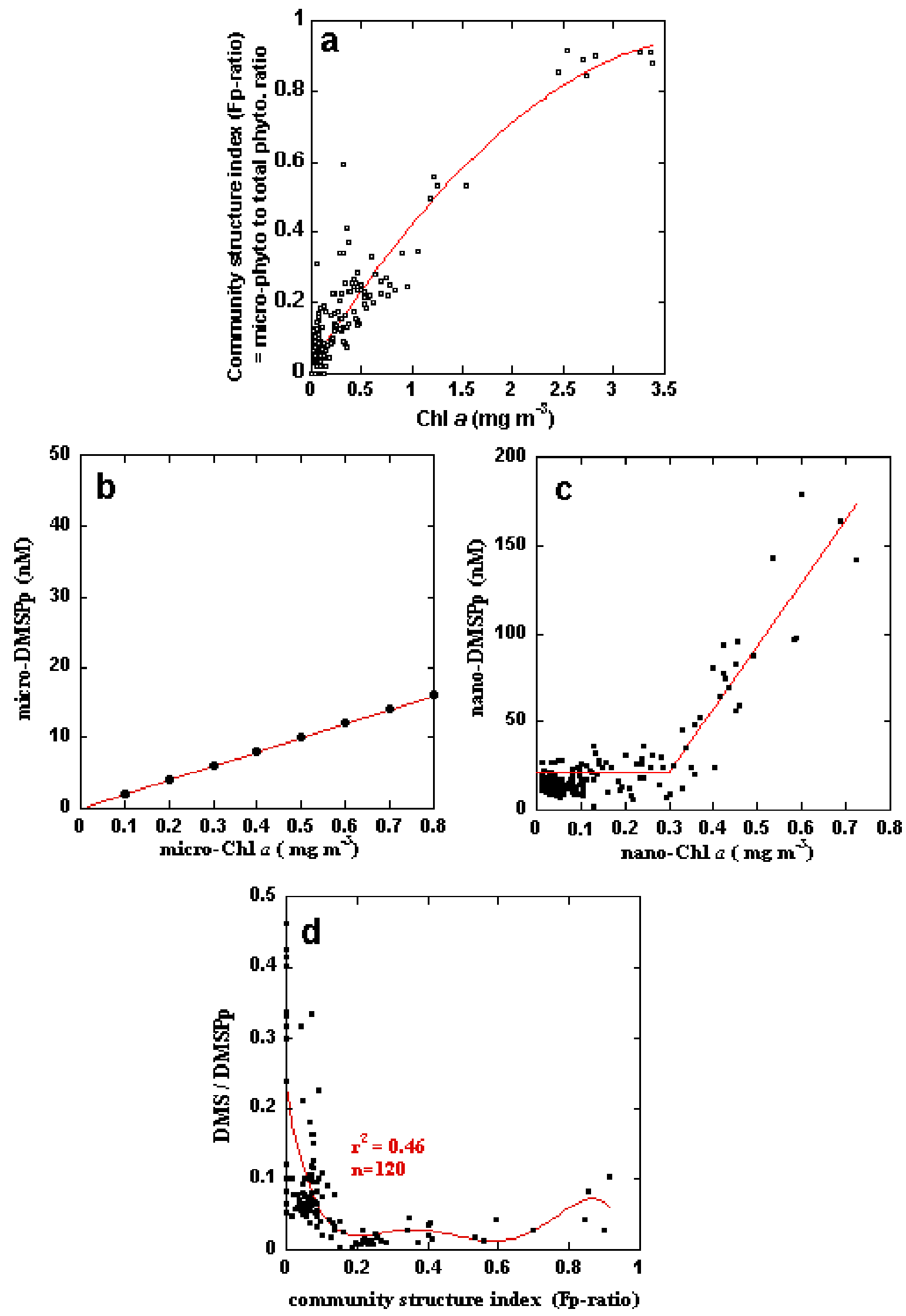

Figure 1: Empirical relationships based on cruise data used to predict DMSPp and DMS concentrations from weekly mean chlorophyll maps from SeaWiFS data ${ }^{\circ}$ : (a) Community structure ratio vs. Chl $a$ concentration $^{\circ}$; (b) microplanktonic DMSPp vs microplanktonic $\mathrm{Chl}^{\circ} a^{\circ}$; (c) nanoplanktonic DMSPp vs. nano- + picoplanktonic $\mathrm{Chl}^{\circ} a^{\circ}$; (d) DMS-to-DMSPp ratio vs. the community structure index. 


\section{Accuracy of the method}

Most of the data points gathered in Figures 1c and 1d were obtained from surveys carried out in Atlantic surface waters with $\mathrm{Chl}^{\circ} a$ levels lower than $3.5 \mathrm{mg} \mathrm{m}^{-3}$ (Aumont et al., 2002). Published and unpublished DMSPp and DMS data from the Atlantic Ocean are shown in Table 1 to independently evaluate the relevance of our diagnostics of DMSPp and DMS concentrations. In this validation data set, $\mathrm{Chl}^{\circ} a$ ranges from $0.1 \mathrm{mg} \mathrm{m}^{-3}$ in the Sargasso Sea (Scarratt et al., 2000) up to $22.4 \pm 5.2 \mathrm{mg} \mathrm{m}^{-3}$ in a Phaeocystis globosa bloom off the Dutch coast near Texel (data courtesy of J. Stefels and S. Oygarden). Our DMSPp estimates show virtually no difference with observations in the oligotrophic waters of the Sargasso Sea. Despite the constant value of 0.92 of the Fp-ratio (see Equation 2b), our relationships also simulate DMSPp levels within roughly a factor of two for the intense Phaeocystis-dominated bloom off the Dutch coast. Moreover, in the Labrador Sea (Cantin et al., 1999) and the Ullsfjord in Northern Norway (Belviso et al., unpubl.) where $\mathrm{Ch}^{\circ} a$ was in the range 2.2-11.5 $\mathrm{mg} \mathrm{m}^{-3}$ and where phytoplankton was dominated by diatoms and, in a lesser extent, by $P$. pouchetii, the accuracy of our DMSPp estimates is better than 50\%. Estimates for DMSPp associated with moderate blooms of Chrysochromulina (Scarratt et al., 2000) and E. huxleyi (Archer et al., 2001) are $-29 \%$ and about $-7 \%$ of the observations, respectively. Estimates for DMSPp associated with blooms of diatoms as observed in the central North Sea, the Balsfjord and Malangen fjords (Belviso et al. unpubl.) are in the range 130\%-2000\% of the observations. Thus, the diagnostic of DMSPp does not resolve DMSPp variability in almost pure diatom blooms but does a fairly good job in areas where prymnesiophytes proliferate, which constitute large tracts of the North Atlantic Ocean.

Contrary to the DMSPp estimates of diatom-dominated blooms which are systematically highly overestimated (see above), DMS estimates are in the range $-64 \%-+655 \%$ of observations. Blooms of mixed populations of diatoms and Phaeocystis exhibit DMS estimates in the range $-2 \%-+160 \%$ of the observations. DMS estimates for moderate blooms of Chrysochromulina sp. and E. huxleyi are $-72 \%$ and $-62 \%$ of the observations. Our model also markedly overestimates DMSPp and DMS levels associated with a bloom of unknown flagellates from the Gulf Stream. In low-DMS areas as observed in the Titanic and Grand Banks sampling sites (Scarratt et al., 2000) estimated DMS is $-30 \%$ and $+130 \%$ of observations, respectively. Finally, the DMS estimate for the Sargasso Sea is only 9\% lower than in the reality. 
Table1. Validation of DMSPp and DMS estimates from Chl $a$ levels measured in contrasted areas of the Atlantic Ocean.

\begin{tabular}{|c|c|c|c|c|c|c|c|c|c|}
\hline $\begin{array}{l}\text { Sampling } \\
\text { sites }\end{array}$ & $\begin{array}{c}\text { Dominant } \\
\text { phytoplankton }\end{array}$ & $\begin{array}{c}\text { Chl } a \\
\left(\mathrm{mg} \mathrm{m}^{-3}\right)\end{array}$ & $\begin{array}{c}\text { Estimated } \\
\text { DMSPp (nM) }\end{array}$ & $\begin{array}{c}\text { Measured } \\
\text { DMSPp (nM) }\end{array}$ & $\begin{array}{c}\text { DMSPp } \\
\text { (Estim.-Meas.) } / \\
\text { Meas. }\end{array}$ & $\begin{array}{c}\text { Estimated } \\
\text { DMS (nM) }\end{array}$ & $\begin{array}{c}\text { Measured } \\
\text { DMS (nM) }\end{array}$ & $\begin{array}{c}\text { DMS } \\
\text { (Estim.-Meas.) / } \\
\text { Meas. } \\
\end{array}$ & References \\
\hline $\begin{array}{c}\text { Sargasso Sea } \\
\text { Grand Banks } \\
\text { Titanic } \\
\text { N. Atl. Drift } \\
\text { Gulf Stream } \\
\end{array}$ & $\begin{array}{c}\text { dinoflagellates } \\
\text { Cryptophyceae } \\
\text { Chaetoceros sp. } \\
\text { Chrysochromulina sp. } \\
\text { dinoflagellates } \\
\text { flagellates } \\
\end{array}$ & $\begin{array}{l}0.10 \\
0.26 \\
0.25 \\
0.52 \\
0.62 \\
0.85 \\
\end{array}$ & $\begin{array}{l}21.5 \\
22.1 \\
22.1 \\
56.1 \\
74.8 \\
109 \\
\end{array}$ & $\begin{array}{c}21.7 \\
39.4 \\
8.5 \\
78.9 \\
30.2 \\
11.7 \\
\end{array}$ & $\begin{array}{c}-0.9 \% \\
-44 \% \\
+160 \% \\
-29 \% \\
+150 \% \\
+830 \% \\
\end{array}$ & $\begin{array}{l}2.0 \\
0.7 \\
0.7 \\
1.2 \\
2.0 \\
3.1 \\
\end{array}$ & $\begin{array}{c}2.2 \\
0.3 \\
1 \\
4.3 \\
2.3 \\
0.3 \\
\end{array}$ & $\begin{array}{c}-9.1 \% \\
+130 \% \\
-30 \% \\
-72 \% \\
-13 \% \\
+940 \% \\
\end{array}$ & Scarratt et al., 2000 \\
\hline $\begin{array}{c}\text { North } \\
\text { Atlantic }\end{array}$ & $\begin{array}{l}\text { E. huxleyi and } \\
\text { P. minimum }\end{array}$ & $\begin{array}{c}0.7 \pm 0.2 \\
(\mathrm{n}=8)\end{array}$ & $\begin{array}{c}80.2 \pm 34 \\
(\mathrm{n}=8)\end{array}$ & $\begin{array}{c}74.7 \pm 20.1 \\
(n=8)\end{array}$ & $-6.8 \%$ & $\begin{array}{c}2.1 \pm 1.0 \\
(\mathrm{n}=8)\end{array}$ & $\begin{array}{c}5.5 \pm 2.3 \\
(\mathrm{n}=8)\end{array}$ & $-62 \%$ & Archer et al., 2001 \\
\hline $\begin{array}{l}\text { Central } \\
\text { North Sea } \\
\text { Apr } 98 \\
\end{array}$ & Diatoms & $\begin{array}{c}2.2 \pm 0.7 \\
(n=30)\end{array}$ & $\begin{array}{c}127 \pm 19 \\
(n=30)\end{array}$ & $\begin{array}{c}19.0 \pm 11.9 \\
(\mathrm{n}=82)\end{array}$ & $+570 \%$ & $\begin{array}{c}5.2 \pm 2.0 \\
(n=30)\end{array}$ & $\begin{array}{l}1.0 \pm 0.9 \\
(n=103)\end{array}$ & $+420 \%$ & $\begin{array}{c}\text { Cruise ESCAPE } 2 \\
\text { Belviso et al., } \\
\text { unpubl. }\end{array}$ \\
\hline $\begin{array}{c}\text { Balsfjord } \\
\text { 8-24 Apr } 97\end{array}$ & $\begin{array}{l}\text { Diatoms } \\
\quad= \\
= \\
= \\
= \\
=\end{array}$ & $\begin{array}{c}6.3 \\
7.8 \\
\\
11.1 \\
10.9 \\
2.7 \\
\end{array}$ & $\begin{array}{c}178 \\
241 \\
\\
379 \\
371 \\
99 \\
\end{array}$ & $\begin{array}{l}22.4 \\
23.3 \\
\\
33.2 \\
17.5 \\
24.7 \\
\end{array}$ & $\begin{array}{l}+690 \% \\
+930 \% \\
+1040 \% \\
+2020 \% \\
+300 \% \\
\end{array}$ & $\begin{array}{c}11.2 \\
15.2 \\
\\
23.9 \\
23.4 \\
7.1 \\
\end{array}$ & $\begin{array}{l}5.0 \\
6.5 \\
\\
6.3 \\
3.1 \\
5.3 \\
\end{array}$ & $\begin{array}{c}+124 \% \\
+134 \% \\
+279 \% \\
+655 \% \\
+34 \% \\
\end{array}$ & $\begin{array}{c}\text { Cruise ESCAPE } 1 \\
\text { Belviso et al., } \\
\text { unpubl. }\end{array}$ \\
\hline $\begin{array}{c}\text { Malangen } \\
\text { 9-23 Apr } 97\end{array}$ & $\begin{array}{c}\text { Diatoms } \\
= \\
= \\
= \\
=\end{array}$ & $\begin{array}{l}5.4 \\
4.5 \\
\\
2.7 \\
5.2\end{array}$ & $\begin{array}{c}141 \\
105 \\
\\
99 \\
132\end{array}$ & $\begin{array}{l}15.1 \\
24.3 \\
\\
12.1 \\
46.9\end{array}$ & $\begin{array}{l}+830 \% \\
+330 \% \\
+720 \% \\
+180 \%\end{array}$ & $\begin{array}{l}8.9 \\
6.7 \\
\\
7.1 \\
8.3\end{array}$ & $\begin{array}{c}11.7 \\
12.7 \\
\\
12.3 \\
9.4\end{array}$ & $\begin{array}{l}-24 \% \\
-47 \% \\
-42 \% \\
-12 \%\end{array}$ & $\begin{array}{c}\text { Cruise ESCAPE } 1 \\
\text { Belviso et al., } \\
\text { unpubl. }\end{array}$ \\
\hline $\begin{array}{c}\text { Ullsfjord } \\
\text { 10-25 Apr } 97\end{array}$ & $\begin{array}{l}\begin{array}{c}\text { Diatoms } \\
=\end{array} \\
\qquad= \\
\text { Diatoms and } \\
\text { P.pouchetii } \\
\text { Diatoms and } \\
\text { P.pouchetii }\end{array}$ & $\begin{array}{l}6.7 \\
5.4 \\
7.1 \\
2.2 \\
5.8\end{array}$ & $\begin{array}{l}195 \\
140 \\
211 \\
129 \\
\\
157\end{array}$ & $\begin{array}{c}32 \\
52.6 \\
\\
92.3 \\
88.3 \\
184\end{array}$ & $\begin{array}{l}+510 \% \\
+170 \% \\
+130 \% \\
+46 \% \\
-15 \%\end{array}$ & $\begin{array}{c}12.3 \\
8.9 \\
\\
13.3 \\
6.4 \\
9.9\end{array}$ & $\begin{array}{c}34 \\
24.5 \\
\\
14.6 \\
5.4 \\
\\
9.7\end{array}$ & $\begin{array}{c}-64 \% \\
-64 \% \\
-9 \% \\
+18 \% \\
-2 \%\end{array}$ & $\begin{array}{c}\text { Cruise ESCAPE } 1 \\
\text { Belviso et al., } \\
\text { unpubl. }\end{array}$ \\
\hline Labrador Sea & $\begin{array}{l}\text { Diatoms and } \\
\text { P. pouchetii }\end{array}$ & 11.5 & 400 & 270 & $+48 \%$ & 25 & nd & nd & Cantin et al., 1999 \\
\hline $\begin{array}{c}\text { North Sea } \\
\text { Off Texel } \\
\text { Apr } 98 \\
\end{array}$ & P. globosa & $\begin{array}{c}22.4 \pm 5.2 \\
(n=14)\end{array}$ & $\begin{array}{c}834 \pm 215 \\
(n=14)\end{array}$ & $\begin{array}{c}360 \pm 73 \\
(n=23)\end{array}$ & $+131 \%$ & $\begin{array}{c}53.6 \pm 13.5 \\
(n=14)\end{array}$ & $\begin{array}{c}20.5 \pm 12.2 \\
(\mathrm{n}=19)\end{array}$ & $+161 \%$ & $\begin{array}{c}\text { Cruise ESCAPE } 2 \\
\text { Belviso et al., } \\
\text { unpubl. }\end{array}$ \\
\hline
\end{tabular}


Thus, contrary to the relationship put forward by Anderson et al. (2001), the present diagnostics of DMS resolve DMS variability both in low and high-DMS areas, even if DMSPp and DMS levels in diatom-dominated blooms of the North Sea and north Norwegian fjords are not accurately represented. This is because the DMSPp-to-Chl $a$ ratio of microphytoplankton there is 2-10 fold lower than that used in Eq. 3 and also because DMSto-DMSPp ratios predicted from Eq. 5 are far away from the ratios measured in the fjords. With these limitations in mind, the method is suitable for use in combination with ocean color data from the Sea-viewing Wide Field -of view Sensor (SeaWiFS).

\section{Application to SeaWiFS ocean color data}

Global fields of $\mathrm{Chl}^{\circ} a$ were obtained from four years (1998-2001) of monthly composites of SeaWiFS $\mathrm{Chl}^{\circ} a$. The data were regridded onto a one degree grid. Equations $2 \mathrm{a}$ and $2 \mathrm{~b}$ were used to estimate the Fp-ratio from SeaWiFS Chl ${ }^{\circ} a$, and both parameters were then used in equations $1 \mathrm{a}, 3,4 \mathrm{a}, 4 \mathrm{~b}$, and 5 to retrieve monthly near-global gridded fields of DMS concentration. Figure 2 shows the monthly mean maps of sea-surface DMS concentration for January, April, July and October. Compared to the results of K\&A2000, our estimates show a much higher spatial variability in particular in frontal and upwelling regions as expected since the distribution of the biology in oceans is far from being uniform. We thus expect this approach to strongly improve the capability of our global source to capture DMS concentration variability at the meso-scale. Note that no data are available at high latitude during winter in both hemisphere because SeaWiFS observations are limited to regions with sufficient solar irradiance. Figure 2 also shows the geographical limits of 4 selected oceanic areas which location roughly correspond to the biogeochemical provinces NADR (northern high latitudes of the Atlantic Ocean), NAST (northern mid-latitudes of the Atlantic Ocean), PEQD (Equatorial Pacific) and SSTC (southern mid-latitudes of the Indian and Atlantic Oceans) as defined by Longhurst et al. (1995) and used by Kettle et al. (1999) to construct monthly maps of the DMS distribution from a database of existing measurements. These regions were selected because they efficiently summarize the similarities and differences between both climatologies, but also because they correspond to well documented regions for which the K\&A2000 database is likely to be the most reliable. Figure 3 displays the seasonal variations of DMS deduced from the K\&A2000 monthly maps and as predicted by SeaWiFS imagery for these 4 regions. 

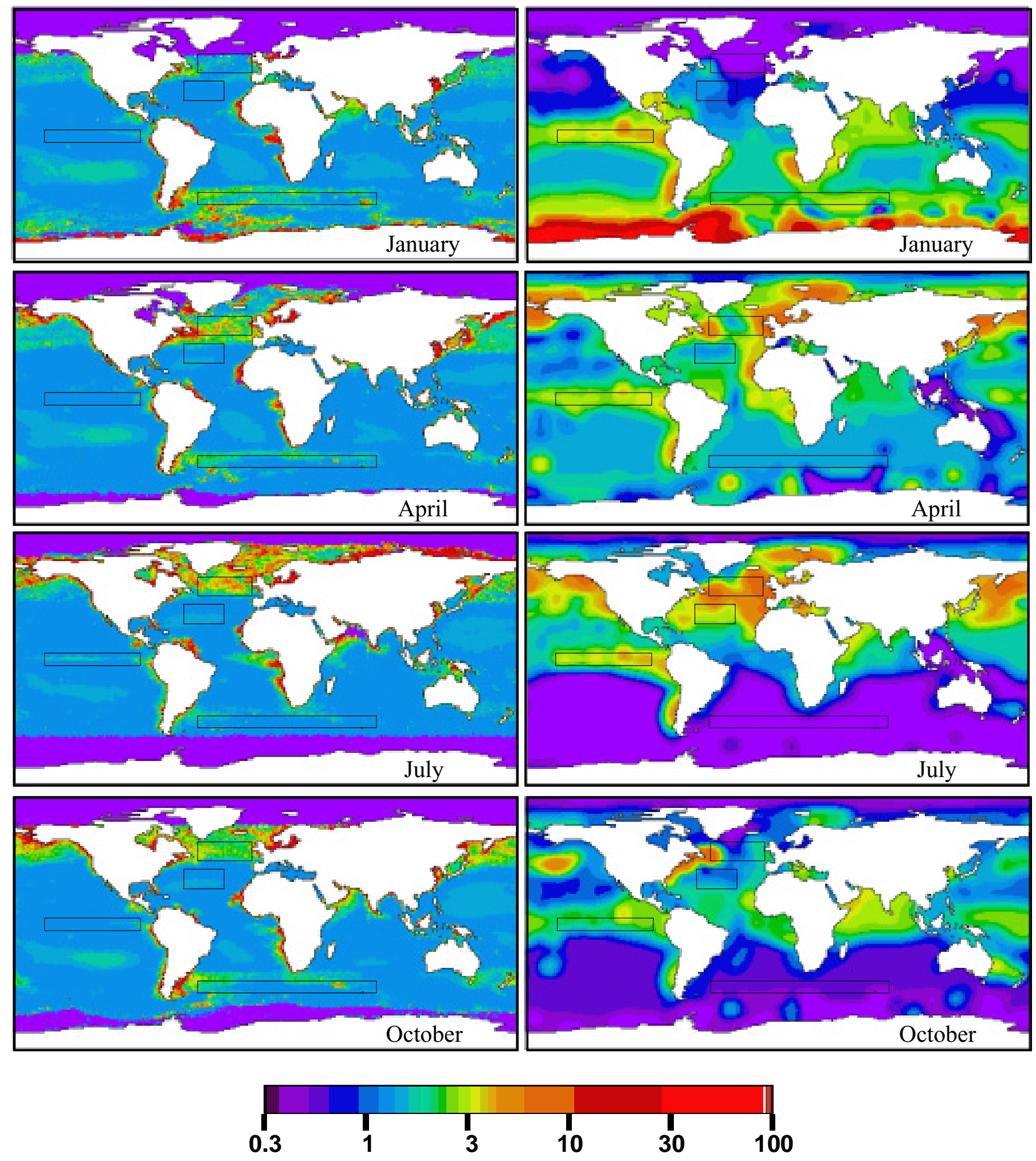

Figure 2: Global climatologies of DMS concentration (nM) for January, April, July and October created from SeaWiFS maps of Chl $a$ (1998-2001) and the database of Kettle and Andreae (2000), left and right columns respectively. 
Substantial differences between the SeaWIFS and K\&A2000 data sets are observed in NADR in late spring and summer (Figure 3a) since the May-June-July maximum concentration of K\&A2000 is roughly twice the SeaWiFS-derived. The seasonal cycles of DMS in NAST compare very well (Figure 3b). Equatorial regions are characterized by small seasonal changes (Figure 3c). However, the DMS simulated in this work is roughly a third of that of K\&A2000. This problem may be related to an underestimate of the DMS-to-DMSPp ratio in these high-nutrient low-chlorophyll areas. Unfortunately the Equatorial Pacific which has been investigated extensively for DMS has received much less attention for DMSPp. It appears that our approach markedly underestimate the amplitude of the DMS seasonal variations in the area SSTC (Figure 3d).
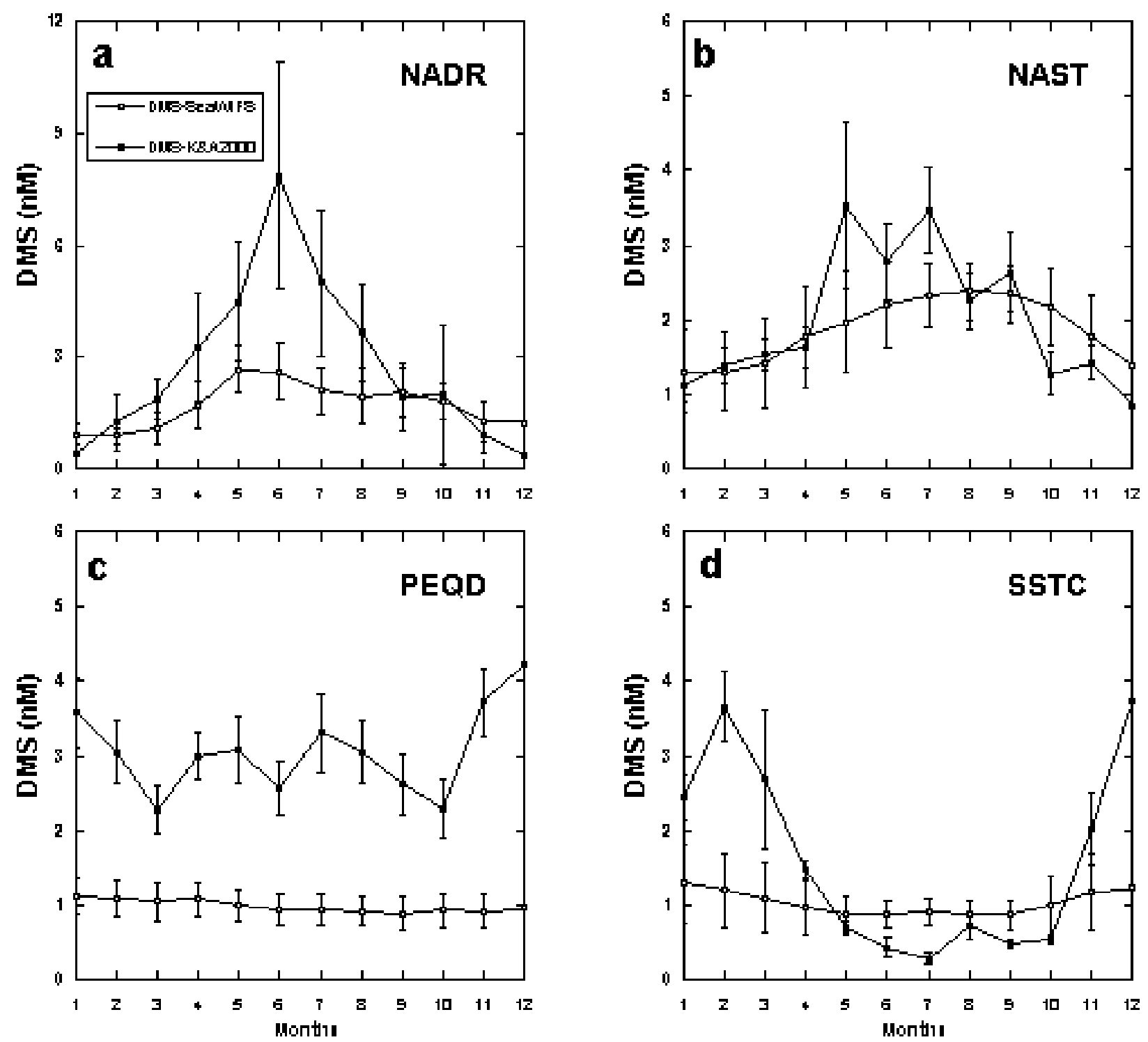

Figure 3: Comparison of the Kettle and Andreae (2000) and SeaWiFS-derived seasonal variabilities of monthly mean DMS concentration in 4 selected biogeochemical provinces (see Figure 2 and text). 


\section{Validation of the SeaWiFS estimates of surface DMS concentration}

Datasets gathered in the comprehensive database of DMS measurements assembled by Kettle et al. (1999) are dated 1997 and earlier. Thus, they are not suitable to carry out evaluations of SeaWiFS-derived DMSPp and DMS concentrations with temporally and spatially coincident observations. This global database has been updated recently (K\&A2000) by the addition of measurements from Belviso et al. (2000), Sciare et al. (1999) and J. Sciare (unpub. data, 1999). Because the parameterizations of DMSPp and DMS make use of data from Belviso et al. (2000), only the measurements from J. Sciare in the Indian Ocean were suitable for the evaluation exercice. Here we used a second independent data set of DMSPp and DMS concentrations measured in a sector of the North Atlantic Ocean between Portugal and Acores $(38 ; \mathrm{N}-44 ; \mathrm{N}, 17 ; \mathrm{W}-22 i \mathrm{~W})$ as part of the recent French research project POMME ( Programme Oc an Multidisciplinaire M so-Echelle). The coupling of mesoscale dynamical and biological processes was one of the major objectives of POMME. During the first leg of the three cruises carried out in 2001 (each roughly 20 days long), a meso-scale hydrographic survey was carried out with a resolution of about $50 \mathrm{~km}$. (see Figure 4). In order to benefit from the high resolution in space and time of the validation data set, we used here SeaWiFS 8-day mean global fields of $\mathrm{Chl}^{\circ} a$ at 9-km resolution instead of monthly composites to compute DMS concentrations.

\subsection{Case 1: Northeast Atlantic surface waters}

The winter mixed layer depth discontinuity zone divides the northeast Atlantic basin into two regions; a rather productive zone, with a strong spring bloom to the north (Figure 5d) associated with a deep winter mixed layer, and a more oligotrophic region to the south, with characteristics similar to those of the subtropical gyre (Figure 5g). DMS and DMSPp measurements were carried out in the upper 80 meters of the water column and analyses were performed at sea following the methodology described in Belviso et al. (2001). The depth of the surface layer that contributes for $90 \%$ of the upwelling marine radiance, $Z_{90}$, varies inversely with $\mathrm{Chl}^{\circ} a$. For the $\mathrm{Chl}^{\circ} a$ values typical of the POMME region (see Figures $5 \mathrm{a}, \mathrm{d}$ and g), $\mathrm{Z}_{90}$ varies from about $20 \mathrm{~m}$ for $\mathrm{Chl}^{\circ} a=0.1^{\circ} \mathrm{mg}^{\circ} \mathrm{m}^{-3}$ to slightly less than $10 \mathrm{~m}$ for $\mathrm{Chl}^{\circ} a$ $=1^{\circ} \mathrm{mg}^{\circ} \mathrm{m}^{-3}$. Consequently, in winter and spring (POMME 1), zonal averages ofDMSPp and DMS concentrations were calculated from surface samples only (Figures 5b, c, e and f). In late summer, during cruise POMME 3, zonal averages of DMSPp and DMS concentrations were calculated from surface and $20 \mathrm{~m}$ depth samples (Figures $5 \mathrm{~h}$ and i). In winter, zonally 


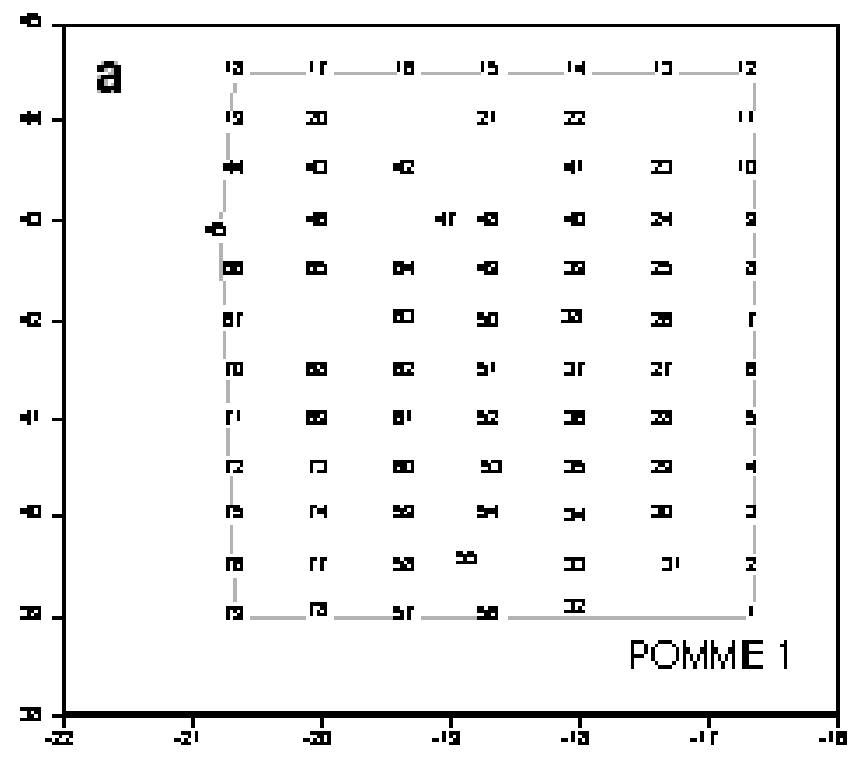

$-13-$

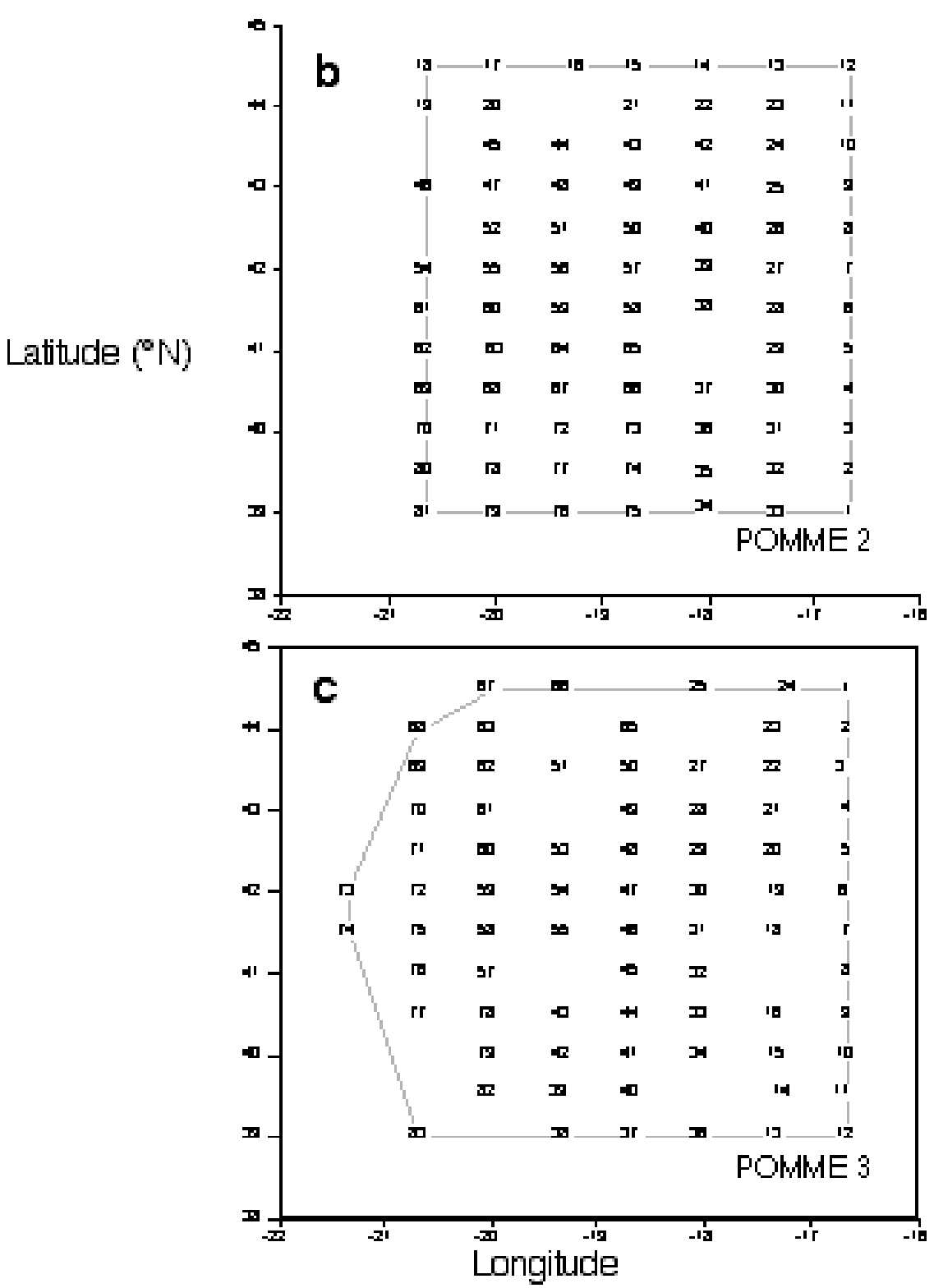

Figure 4: Network of hydrographic stations from which zonal averaged DMSPp and DMS concentrations were calculated $^{\circ}$ : (a) cruise POMME 1 (Feb. 3 to Feb. 23, 2001) ; $^{\circ}$ (b) cruise POMME 2 (Feb. 22 to Mar. 13, 2001) ${ }^{\circ}$; (c) cruise POMME 3 (Aug. 23 to Sep. 13, 2001). Figures in the maps correspond to station numbers. 
averaged SeaWiFS-derived DMSPp concentrations are 1.5-6 fold higher than observations north of $42{ }_{i} \mathrm{~N}$ (Figures $5 \mathrm{~b}$ ). The agreement is better south of $42 \mathrm{i}_{\mathrm{N}}$ where simulated and measured DMSPp concentrations are within a factor of two. Corresponding simulated DMS concentrations are 1.5-4 fold higher than observations north of $42{ }_{i} \mathrm{~N}$, and 1.2-2.2 fold higher than observations south of $42{ }_{i} \mathrm{~N}$ (Figure $5 \mathrm{c}$ ). In spring, north of $42{ }_{i} \mathrm{~N}$, simulated DMSPp is 1.5-3 fold higher than observations whereas, south of $42{ }_{i} \mathrm{~N}$, simulated DMSPp is in very close agreement with the observations (Figure $5 \mathrm{e}$ ). North of $42{ }_{i} \mathrm{~N}$, DMS concentrations are within a factor of two of the observations. The simulations fail to reproduce the high-DMS concentrations measured south of $40 \nmid \mathrm{N}$ (Figure $5 \mathrm{f}$ ). In this area, however, the zonal variability of DMS was huge (see error bars) because the DMS highs were restricted to the south-west sector of the domain (data not shown). This situation where simulated DMS is markedly underestimated whereas DMSPp is well simulated very much ressembles the situations associated with moderate blooms of Chrysochromulina sp. and E. huxleyi in Atlantic waters (Table 1). In late summer, simulated DMSPp and DMS concentrations are within a factor of two of observations. Thus, it appears that the diagnostics of the DMSPp and DMS concentrations mainly reduce the zonal variability of the compounds in northeast Atlantic surface waters at mid-latitudes. This mainly results from the overestimate of DMSPp concentration in the deep winter mixed layer and from the underestimate of the DMS spring bloom in more stratified waters. The DMSPp and DMS content of the more oligotrophic waters of the northern edge of the North Atlantic subtropical gyre in late summer are predicted with higher accuracy.

\subsection{Case 2: Indian Ocean surface waters}

DMSP and DMS concentrations were measured in December 1997 and August 1998 during cruises of R/V Marion Dufresne (Sciare et al. (1999), Sciare et al. unpublished, respectively). Each trip was comprised of three legs: (1) from La R union Island $(20 ; S, 56 ; E)$ to Crozet Island $(46 ; \mathrm{S}, 50 ; \mathrm{E}) ;(2)$ from Crozet Island to Kerguelen Island $\left(49_{j} \mathrm{~S}, 69_{i} \mathrm{E}\right)$; and (3) from Kerguelen Island to Amsterdam Island $(37 ; \mathrm{S}, 77 ; E)$. Figure 6 compares the SeaWiFS-derived DMSPp and DMS concentrations with observed sea-surface DMSP and DMS concentrations in December 1997 and August 1998. Weekly mean chlorophyll maps from SeaWiFS data were used for evaluating predicted versus observed DMSP and DMS levels. Note that Figures $6 \mathrm{a}$ and $6 \mathrm{c}$ shows observed total DMSP levels (DMSPt), i.e. the cumulated levels of particulate DMSP (DMSPp) and dissolved DMSP (DMSPd), whereas Equations 3a and $3 b$ involve only pDMSP. Indeed, in subtropical and subantarctic waters of the Indian Ocean during December 

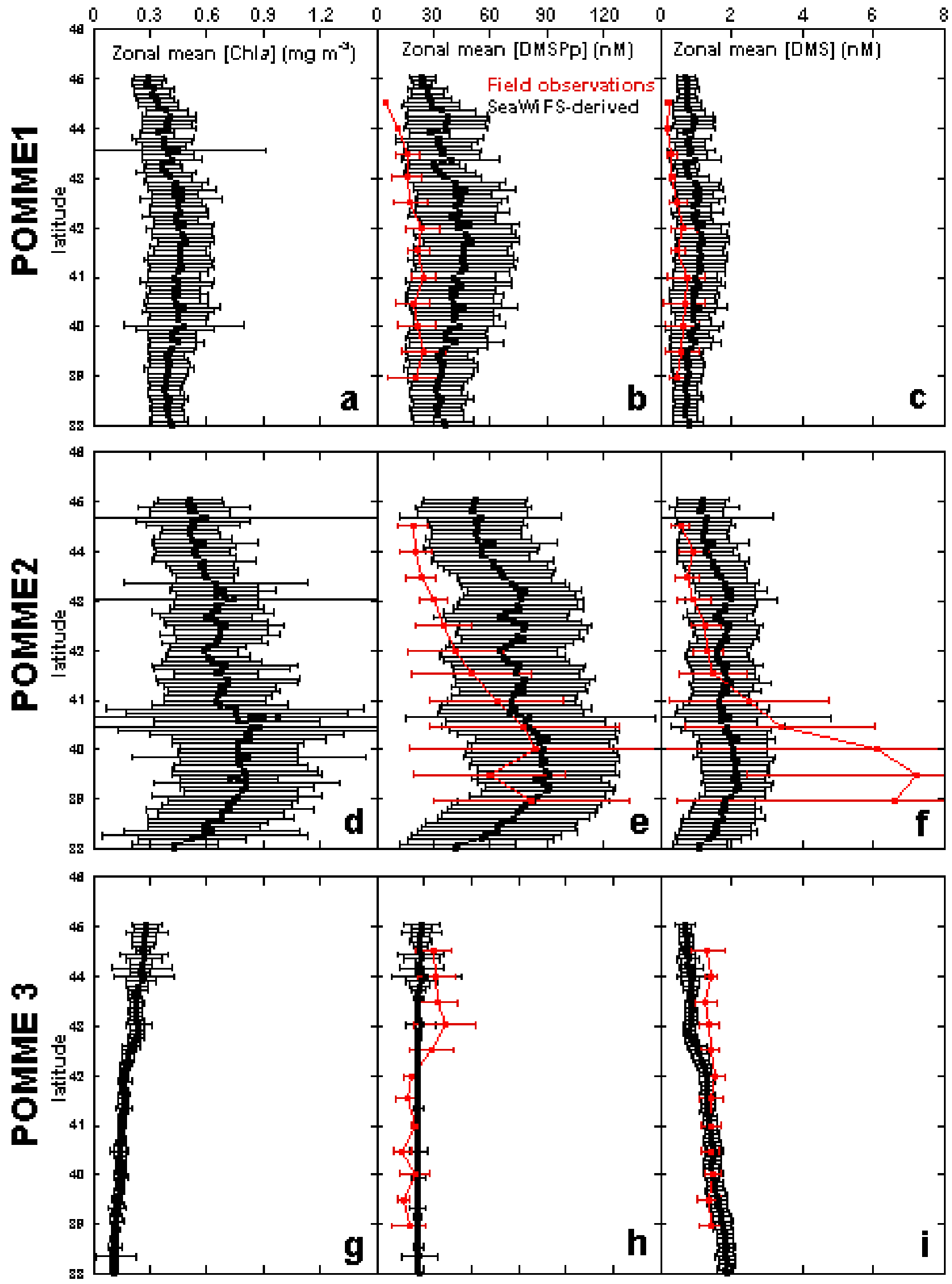

Figure 5: Comparison of observed zonal averaged concentrations of Chl $a$ (from SeaWiFS), DMSPp and DMS, with SeaWiFS-derived predictions of DMSPp and DMS concentrations in the POMME area. 
1997 and August 1998, DMSPd accounted for 20 to 80\% of DMSPt. Dissolved DMSP is a very labile compound usually exhibiting turnover times on the order of hours rather than days (e.g., Zubkov et al. 2001). Since DMSPd is released from phytoplankton by direct excretion, grazing or viral lysis, it is expected that measured DMSPd results from the turnover of DMSPp produced in the previous few days. Thus, it is more appropriate to compare predicted DMSPp and observed DMSPt than to compare directly predicted and observed DMSPp concentrations. In other words, observed DMSPt concentrations are more adapted to a comparison with predicted mean DMSPp because they provide a longer integration over time. As seen in Figure 6a, SeaWiFS data in combination with Equations 1-5 markedly overestimate DMSPp in August 1998 inside the chlorophyll patch. The SeaWiFS data predict a four- to five-fold enhancement of DMSPp in the patch, whereas observations show a twofold increase. Outside the chlorophyll patch and during the first $3 / 4$ of the winter cruise, predicted and observed DMSP concentrations are almost the same. During the last fourth of the cruise SeaWiFS data overestimate DMSPp about 2-fold. In August, observed and predicted DMS levels exhibit almost similar fluctuations in the range 0.4-3 nM except near cruise end as for DMSPp (Figure 6b). It appears that use of SeaWiFS data in combination with Equations 1-5 generally compares very well with the winter observations.

Three major DMSPp peaks are predicted via the SeaWiFS data at the location of the chlorophyll patches crossed during the December 1997 trip (Figure 6c). The predicted magnitudes are in close agreement with the field observations except near cruise end (Kerguelen Plateau), where predicted DMSPp is two-fold higher than observed. Outside these chlorophyll patches, predicted DMSPp concentrations are similar (subtropical waters) or up to three-fold lower than observed. Three major DMS peaks are also predicted by the SeaWiFS data at the location of the chlorophyll patches (Figure 6d). DMS field observations also were clearly enhanced at these locations. The SeaWiFS-derived magnitude of the first two DMS peaks, however, is considerably lower (5- to 10-fold) than observed, with better agreement on the third peak. Predicted baseline DMS, outside the chlorophyll patches, is similar (subtropical waters) and up to 20-fold lower than observed. 

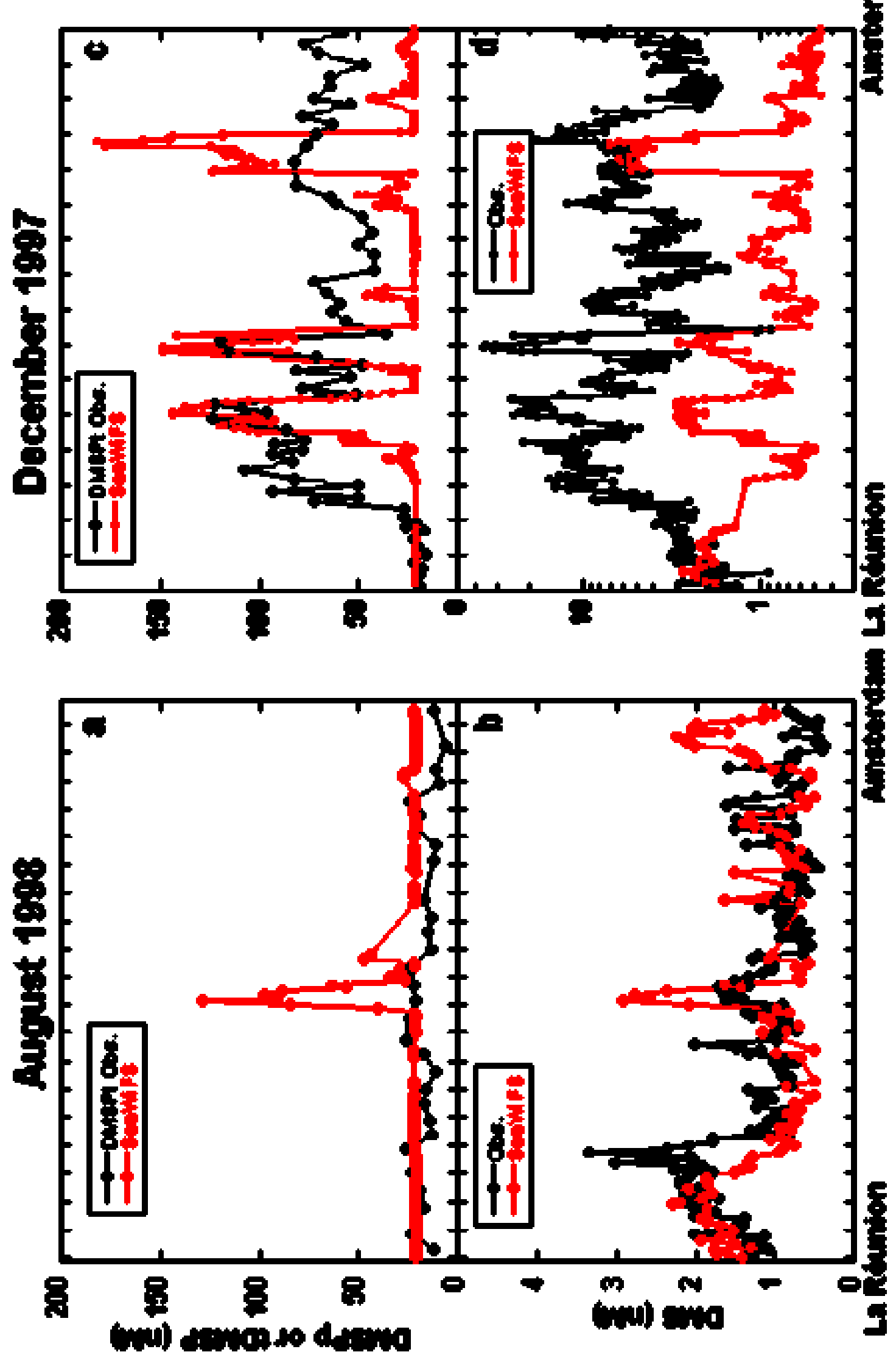

Figure 6: Comparison of observed concentrations of total DMSP (DMSPt) and DMS concentrations with SeaWiFS-derived predictions of DMSPp and DMS concentrations in the Indian Ocean along the track of R/V Marion Dufresne from La R union to Amsterdam Island. 


\section{Discussion}

It appears that one major problem with SeaWiFS-based predictions is an underestimation of DMS concentrations in subantarctic waters during the summer. Again, this situation where simulated DMS is markedly underestimated whereas DMSPp is well simulated very much ressembles the situations associated with the moderate blooms of Chrysochromulina sp. and E. huxleyi in Atlantic waters (Table 1), and the spring bloom in the POMME area. The approach described here in employing SeaWiFS data results in an oceanic DMS baseline concentration of about $0.5 \mathrm{nM}$, about 4-fold lower than the baseline of $2.3 \mathrm{nM}$ reported by Anderson et al. (2001). Both Figure $6 \mathrm{~b}$ and Table 1 show that SeaWiFS-derived DMS concentrations vary over a wider range of values (0.5-41 $\mathrm{nM}$ ) than DMS concentrations derived from the CJQ index of Anderson et al. (2001). The use of weekly mean chlorophyll maps from SeaWiFS data in combination with the non-linear Equations 2-5 improve the representation of the low- and high-DMS areas. Evidences are given in Table 1, Figures $3 b$, $5 \mathrm{i}, 6 \mathrm{~b}$ and $6 \mathrm{~d}$ of the proper representation of DMS concentrations in subtropical gyres. Evidences are also given in Table 1 of the proper representation of DMS levels associated with Phaeocystis blooms. In the winter hemispheres at mid-latitudes the difference between observed and simulated DMS levels is generally lower than a factor of two except north of $42 i \mathrm{~N}$ where larger discrepancies were noted. In the winter hemisphere at high latitudes in the absence of SeaWiFS data and to provide a global coverage of the oceanic domain, we recommend, according to Belviso et al. (2000) and the POMME 1 survey (Figure 5c), to take $0.2 \mathrm{nM}$ as the winter reference for marine DMS. As shown in Table 1, Figures $5 \mathrm{f}$ and $6 \mathrm{~d}$, our approach fails to reproduce the observed high (4-30 nM) DMS levels associated with the fairly well estimated moderate (60-150 nM) DMSP levels. The largest discrepancy was observed in the Indian Ocean during summer. Unfortunately no supporting parameters were measured during the December 1997 cruise so the dominant phytoplanktonic populations in these waters are unknown. Very high DMS levels in association with very high concentrations of DMSPd and low DMSPp (Sciare et al., 1999) could result from senescence of a phytoplanctonic bloom. Indeed, in the senescence phase, phytoplankton autolysis or zooplankton grazing releases to solution compounds present in the phytoplanktonic cell, where they can undergo microbial degradation. Enzymatic cleavage by DMSP lyase is though to be the major process for DMS production in marine environments. Dissolved DMSP is available to bacteria in surface waters. To maintain DMS and DMSPd at the very high levels observed in December 1997 it may be suggested, according to Kiene et al. (2000) who 
highlighted the high metabolic value of DMSPd for bacteria, that bacterial sulfur demand and bacterial DMS consumption in the area was low, and that a relatively high proportion of DMSPd was available for DMS production from bacterial enzymatic cleavage of DMSP. Pathways for non-bacterial production of DMS have been also acknowledged, e.g. Steinke et al. (2002), where the majority of DMSP lyase activity occurred in particles $>10 \mu \mathrm{m}$ and was related to the presence of dinoflagellates. Fiala et al. (1998) reported at the KERFIX station, 60 miles southwest of the Kerguelen Islands, that the $>10 \mu \mathrm{m}$ size fraction contributed $60 \%$ to total phytoplankton integrated biomass during summer blooms. Large autotrophic dinoflagellates, mainly Prorocentrum spp., were associated with the summer phytoplankton maxima and accounted for $>80 \%$ of the total autotroph carbon biomass. In November and December, the presence of the large heterotrophic dinoflagellates Protoperidinium spp. and Gyrodinium spp. contributed a high proportion of total carbon biomass. Archer et al. (2001) and Steinke et al. (2002) agreed on the presence of dinoflagellates in E. Huxleyi blooms from the northern North Sea and the North Atlantic. The Chrysochromulina sp. bloom investigated by Scarratt et al. 2000 was in fact located very close to the North Atlantic Drift sampling station where dinoflagellates were the dominant phytoplankton. Thus it is not unlikely that dinoflagellates were also present in the Chrysochromulina sp. bloom. A phytoplankton bloom took also place in the southwestern portion of the POMME area during spring 2001 (Figure 5e). DMSPp size fractionation experiment carried out there showed that DMSPp was mainly present in the $<10 \mu \mathrm{m}$ fraction (Belviso, unpubl.). According to Belviso et al. (2001), it is likely that prymnesiophytes and pelagophytes accounted for nanoplanktonic DMSPp and that dinoflagellates accounted for the remaining microplanktonic form of DMSPp in North Atlantic waters. Thus, evidences are given of the presence of dinoflagellates in the four moderate phytoplankton blooms investigated where DMSPp was well diagnosed but DMS markedly underestimated by SeaWiFS data in combination with Equations 1-5. Assuming that all other DMS controlling processes were equal, a weak assumption, it is suggested that the DMS enhancements resulted from the DMSP lyase activities of dinoflagellates. 


\section{Conclusion}

Our SeaWiFS-derived climatology of sea surface DMS concentration is an alternative (1) to K\&A2000 whose monthly fields of DMS concentration still lack of stability and heavily rely on a scheme of substitutions especially in regions of the southern hemisphere where observations remain poorly numerous, and (2) to the approach of Anderson et al. (2001) which do not resolve DMS variability in low-DMS areas. A means to characterize the global distribution of particulate DMSPp, the major intermediate in DMS production, and a key for the investigation of the interannual variations of the marine source of DMS are also provided. The diagnostic relationships adopted here in combination with either ship-based or remotelysensed Chl levels resolve the DMS variability in subtropical gyres, in large blooms of mixed populations of diatoms and Phaeocystis sp., in massive blooms of Phaeocystis sp. but fails for large almost pure blooms of diatoms. Moreover, they provide accurate estimates of DMSPp concentrations in spring and summer moderate blooms of mixed populations of prymnesiophytes and dinoflagellates in the North Atlantic and, possibly, in subantarctic waters of the Indian Ocean. Related DMS levels, however, are markedly underestimated, a situation which results in a clear reduction of the seasonal amplitude of DMS variations. Our method does not resolve the variations of DMS in the Equatorial Pacific.

The Fp-ratio is clearly the critical parameter of the method describes in this paper. We estimated this parameter from the $\mathrm{Chl}^{\circ} a$ concentration with the help of a simple relationship whereas it also strongly depends on the phytoplankton populations. Use of more complete estimates of the Fp-ratio based on biological modeling (e.g., Laws et al., 2000) would likely improve the accuracy of the method. Improved remote sensing techniques may also provide additional information on the phytoplankton population (Loisel et al., 2001) and it is likely that recent high-performance ocean color sensors such as MODIS or MERIS would enable the global survey of some phytoplankton-related parameters.

\section{Acknowledgements}

We wish to acknowledge the Goddard Active Archive Centre, under the auspices of the National Aeronotics and Space Administration, for provision of the SeaWiFS ocean colour data. Chlorophyll a concentrations in North Atlantic waters during both ESCAPE cruises (EU financed under contract MAS3-CT96-0050) are courtesy of J. Stefels and S. Oygarden. DMSP and DMS concentrations in Indian Ocean subtropical and subantarctic waters during winter are courtesy of J. Sciare. We extend our thanks to I. Lefevre, C. Valant and O. Aumont 
who contributed to DMSP/DMS analyses during the POMME cruises. This work was supported by the national program PROOF of INSUE/CNRS.

\section{References}

Anderson, T.R., Spall, S.A.,Yool, A., Cipollini, P., Challenor, P.G., Fasham, M.J.R., 2001. Global fields of sea surface dimethylsulfide predicted from chlorophyll, nutrients and light. Journal of Marine Systems 30, 1-20.

Archer, S.D., Widdicombe, C.E., Tarran, G.A., Rees, A.P., Burkill, P.H., 2001. Production and turnover of particulate dimethylsulphoniopropionate during a coccolithopohore bloom in the northern North Sea. Aquatic Microbial Ecology 24, 225-241.

Aumont, O., Belviso, S., Monfray, P., 2002. Dimethylsulfoniopropionate (DMSP) and dimethylsulfide (DMS) sea surface distributions simulated from a global 3-D ocean carbon cycle model. Journal of Geophysical Research, in press.

Belviso, S., Morrow, R., Mihalopoulos, N., 2000. An Atlantic meridional transect of surface water DMS concentrations with 10-15 km horizontal resolution and close examination of ocean circulation. Journal of Geophysical Research 105 (D11), 14,423-14,431.

Belviso, S., Claustre, H., Marty, J.-C., 2001. Evaluation of the utility of chemo-taxonomic pigments as a surrogate for particulate DMSP. Limnology and Oceanography 46 (4), 989-995.

Cantin, G., Levasseur, M., Schultes, S., Michaud, S., 1999. Dimethylsulfide (DMS) production by size-fractionated particles in the Labrador Sea. Aquatic Microbial Ecology 19, 307-312.

Claustre, H., 1994. The trophic status of various oceanic provinces as revealed by phytoplankton, pigment signatures. Limnology and Oceanography 39 (5), 1206-1210.

Fiala, M., Kopczynska, E.E., Jeandel, C., Oriol, L., Vetion, G., 1998. Seasonal and interannual variability of size-fractionated phytoplankton biomass and community structure at station Kerfix, off the Kerguelen Islands, Antarctica. Journal of Plankton Research 20 (7), 1341-1356.

Jones, A., Roberts, D.L., Woodage, M.J., Johnson, C.E., 2001. Indirect sulphate aerosol forcing in a climate model with an interactive sulphur cycle. Journal of Geophysical Research 106 (D17), 20,293-20,310.

Kettle, A.J., et al., 1999. A global database of sea surface dimethylsulfide (DMS) measurements and a procedure to predict sea surface DMS as a function of latitude, longitude, and month. Global Biogeochemical Cycles 13 (2), 399-444.

Kettle, A.J., Andreae, M.O., 2000. Flux of dimethylsulfide from the oceans: A comparison of updated data sets and flux models. Journal of Geophysical Research 105 (D22), 26,79323,808 .

Kiene, R.P., Linn, L.J., Burton, J.A., 2000. New and important roles for DMSP in marine microbial communities, Journal of Sea Research 43 (3-4), 209-224,

Laws, E.A., Falkowski, P.G., Smith Jr., W.O., Ducklow, H., McCarthy, J.J., 2000. Temperature effects on export production in the open ocean. Global Biogeochemical Cycles 14 (4), 1231-1246.

Loisel, H., Bosc, E., Stramski, D., Oubelkheir, K., Deschamps, P.Y., 2001. Seasonal variability of the backscattering coefficient in the Mediterranean Sea based on Satellite SeaWiFS imagery. Geophysical Research Letters 28 (22), 4203-4206.

Longhurst, A., Sathyendranath, S., Platt, T., Caverhill, C., 1995. An estimate of global primary production in the ocean from satellite radiometer data. Journal of Plankton Research 17 (6), 1245-1271. 
Scarratt, M.G., Levasseur, M., Schultes, S., Michaud, S., Cantin, G., V zina, A. Gosselin, M. de Mora, S.J., 2000. Production and consumption of dimethylsulfide (DMS) in North Atlantic waters. Marine Ecolology Progress Series, 204, 13-26.

Sciare, J., Mihalopoulos, N., Nguyen, B.C., 1999. Summertime seawater concentrations of dimethylsulfide in the Western Indian Ocean: reconciliation of fluxes and spatial variability with long-term atmospheric observations. Journal of Atmospheric Chemistry 32, 357-373.

Steinke, M., Malin, G., Archer, S.D., Burkill, P.H., Liss, P.S., 2002. DMS production in a coccolithophorid bloom: evidence for the importance of dinoflagellate DMSP lyases. Aquatic Microbial Ecology 26, 259-270.

Vidussi, F, Claustre, H, Manca, B.B., Luchetta, A., Marty, J.C., 2001. Phytoplankton pigment distribution in relation to upper thermocline circulation in the eastern Mediterranean Sea during winter. Journal of Geophysical Research 106 (C9), 19,939-19,956.

Zubkov, M.V., Fuchs, B.M., Archer, S.D., Kiene, R.P., Amann, R., Burkill, P.H., 2001. Linking the composition of bacterioplankton to rapid turnover of dissolved dimethylsulfonio-propionate in an algal bloom in the North Sea. Environmental Microbiology 3, 304-311. 